\title{
Angiogenic Effect of Leptin in the Quail Chorioallantoic Membrane
}

\author{
Pavel Výboh ${ }^{1}$, Michal Zeman ${ }^{1,2}$, Boris Bilčík ${ }^{1}$, Božena Šárniková ${ }^{1}$, Lubor Košt’ál ${ }^{1}$ \\ ${ }^{1}$ Institute of Biochemistry and Genetics, Slovak Academy of Sciences, Ivanka pri Dunaji, Slovak Republic \\ ${ }^{2}$ Comenius University, Faculty of Natural Sciences, Bratislava, Slovak Republic
}

Received March 9, 2009

Accepted September 8, 2009

\begin{abstract}
Leptin, the product of $o b$ gene, beside its key role in the control of body weight and food consumption, can be involved in the control of embryonic development. Leptin administration in ovo accelerated the embryonic and post-embryonic development in Japanese quail. Although the mechanisms of leptin effects on growth and development acceleration are not clear, stimulation of angiogenesis represents one of plausible explanations. Therefore, the aim of the present study was to investigate the pro-angiogenic effect of leptin in vivo in the quail chorioallantoic membrane (CAM). The recombinant murine leptin $(10,100$, and $1000 \mathrm{ng})$ was applied either ex ovo on the CAM surface of ex ovo incubated embryos at embryonic day 7 (ED7) or in ovo into the egg albumen at ED5. Changes in blood vessels were quantified by the fractal analysis providing the fractal dimension (Df) estimate. Leptin administered in ovo was more efficient in stimulation of angiogenesis than the ex ovo treatment, since $10 \mathrm{ng}$ dose elicited significantly higher $(P<0.001)$ stimulation of vessel development of the CAM under the air cell than it did after ex ovo cultivation. Our study confirmed that exogenously applied leptin was able to stimulate angiogenesis in CAM. Leptin-mediated stimulation of angiogenesis may improve nutrient utilization from the yolk and explain at least partially the accelerating effect of leptin on avian embryo growth and development.
\end{abstract}

Angiogenesis, leptin, chorioallantoic membrane, Japanese quail, fractal dimension

Angiogenesis is a process that refers to the growth of new blood vessels from a preexisting vasculature. It is closely associated with endothelial cell migration and proliferation. Endothelial cells are particularly active during embryonic development and therefore the CAM assay has been considered as a very useful in vivo method for the quantification of angiogenesis and development of new drugs (Falkner et al. 2004).

The angiogenic effect has been demonstrated for numerous endogenous peptides including leptin (Ribatti et al. 2007). Leptin is an adipocytokine with pleiotropic effects. It is produced predominantly in adipocytes and its major role in mammals is the control of food intake and energy expenditure (Campfield et al. 1995). Since both processes are of key importance also for farm animals, possible roles of leptin in the neuroendocrine control of these species have been studied (Máčajová et al. 2004). The physiological role of leptin in poultry is not clear and the identity of the natural ligand for leptin receptors is controversial. Avian leptin cDNA has been cloned (Taouis et al. 1998) and its mRNA was detected in the adipocyte and liver (Taouis et al. 1998; A shwell et al. 1999). However, a number of research groups raised the question whether the reported chicken leptin cDNA nucleotide sequence represents genuine chicken leptin (Ohkubo and Adachi 2008). On the other hand, the leptin receptor has been cloned and proved by several research groups (Horev et al. 2000; Ohkubo et al. 2000) in birds and various physiological responses were observed after exogenous leptin administration. Therefore, it is assumed that leptinlike activity exists also in birds (Ohkubo et al. 2008).

Previous studies showed that the administration of leptin in ovo accelerated the embryonic and post-embryonic development in Japanese quail (Máčajová et al. 2002; Lamošová et al. 2003). However, the mechanisms of how leptin can accelerate embryonic growth are not

Address for correspondence:

Ing. Pavel Výboh, CSc.

Institute of Biochemistry and Genetics

Slovak Academy of Sciences

Moyzesova 61, 90028 Ivanka pri Dunaji

Slovak Republic

Phone: +4210245943232

Fax: + 4210245943932

E-mail: pavel.vyboh@savba.sk

http://www.vfu.cz/acta-vet/actavet.htm 
understood. Since leptin has been shown to stimulate angiogenesis under in vitro and in vivo conditions (Sierra-Honigmann et al. 1998; Talavera-Adame et al. 2008) we expect that activation of vessel development can contribute to better exchange of nutrients and gasses between the developing embryo and the yolk and gas environment. Therefore, the aim of our study was to determine the effect of leptin on the development of CAM in Japanese quail under in vivo conditions using two experimental approaches (ex ovo and in ovo).

\section{Materials and Methods}

Fertilized eggs of Japanese quail (Coturnix japonica) from our breeding colony (Laying Line 01 Ivanka pri Dunaji) were incubated in a forced draught incubator at $37{ }^{\circ} \mathrm{C}$ and $50-60 \%$ relative humidity. Three different doses of recombinant murine leptin (PeproTech, Great Britain), 10, 100, and $1000 \mathrm{ng}$, were administered under two treatment conditions: ex ovo (shell-less) and in ovo.

To prepare for ex ovo culture, the eggs at ED3 were wiped with $70 \%$ ethanol in a sterile laminar flow hood. The eggs were then opened and the embryos transferred into the six-well tissue culture plates (TPP, Switzerland), and returned to humidified incubator for the next 4 days (Parsons-Wingerter et al. 1998, 2000). At ED7, leptin was prepared to the desired concentrations in pre-warmed sterile phosphate buffered saline (PBS); $0.5 \mathrm{ml}$ of solution containing either the leptin $(10,100$, and $1000 \mathrm{ng}$ ) or the vehicle buffer was added gently in drops on the surface of each CAM. The embryos were then incubated at $37{ }^{\circ} \mathrm{C}$ for another $24 \mathrm{~h}$, at which time they were fixed in pre-warmed fixative (4\% paraformaldehyde/ $\%$ glutaraldehyde/ PBS) for 2 days at room temperature. Thereafter, the CAMs of fixed embryos were carefully dissected, mounted without folds onto glass slides and dried.

In the second approach we applied the same protocol as in previous studies (Máčajová et al. 2002; Lamošová et al. 2003). Leptin at doses of 10,100, and $1000 \mathrm{ng}$ in $50 \mu \mathrm{l}$ of sterile PBS was injected into the egg albumen at ED5. The control group received $50 \mu \mathrm{l}$ of PBS only. Before injection, the eggs were disinfected with $70 \%$ ethanol and after injection the holes in eggs were closed by wax. At ED10, the eggs were opened so that the air cells were not damaged and the embryos were removed. The parts of egg shells with air cells were rinsed with PBS and CAMs were fixed in pre-warmed fixative as above for $24 \mathrm{~h}$ at room temperature $\left(22 \pm 1{ }^{\circ} \mathrm{C}\right)$. Thereafter, the fixative was removed and CAMs were dried.

Images were obtained using digital camera (Canon EOS 40D with Canon EF $100 \mathrm{~mm} \mathrm{f} / 2.8$ USM macro lens). The CAMs were illuminated using either transilluminator (Kaiser Slimlite 5000K Lightbox, for ex ovo CAMs) or ring flash (Canon MR-14EX Ring Lite, for in ovo CAMs) as a source of homogenous light. The subsequent image processing was performed with the ImageJ software (Abramoff et al. 2004). For quantification of the CAM arteries, the contrast and brightness of the obtained images were adjusted (Plate III, Fig. 1). A square region $(512 \times 512$ pixels $)$ from the area with distal arterial branches was selected and used for further processing. The images were then binarized using manual tresholding and skeletonized to obtain final image where each vessel had the thickness of a single pixel (Plate IV, Fig. 2). The fractal coefficient (Df) was calculated following the procedures described by Parsons-Wingerter et al. (1998, 2000). Df, a statistical descriptor of space-vessel filling area and length (Kirchner et al. 1996), was determined using an ImageJ plugin, implementing the method of box counting. The CAM image was overlaid with a series of square boxes of decreasing size (denoted in pixel, $\mathrm{p}$ ). The number of boxes $\left(\mathrm{N}_{\mathrm{p}}\right)$ that contain at least one black pixel was counted. The negative value of the least squares regression slope of the plot of $\log \mathrm{N}_{\mathrm{p}}$ versus $\log \mathrm{p}$ yielded $\mathrm{D}_{\mathrm{f}}\left(\mathrm{r}^{2} \geq 0.96\right)$.

The results were statistically evaluated by one-way ANOVA followed by Fisher PLSD post hoc test.

\section{Results}

We found a significant dose-dependent effect of leptin on CAM angiogenesis in both in vivo experimental models. In the ex ovo model the dose of $10 \mathrm{ng}$ of leptin administered onto the CAM surface did not influence the vessel density but the doses of 100 and $1000 \mathrm{ng}$ significantly (both $P<0.001$ ) stimulated angiogenesis (Fig. 3). Mortality of the embryos was maximum $35 \%$ and did not depend on the drug dose/control treatment.

In the in ovo approach, already $10 \mathrm{ng}$ of leptin administered directly into the egg albumen significantly $(P<0.001)$ stimulated angiogenesis (Fig. 4). Embryo mortality upon drug administration was maximum 5\% and did not depend on the drug dose. In both approaches the stimulating effect of leptin increased with the dose administered.

The comparison of both experimental conditions of CAM demonstrates that administration of the hormone into the egg albumen represented a more sensitive way of angiogenesis stimulation. 




Fig. 3. Effect of leptin administered ex ovo at embryonic day 7 on angiogenesis in quail CAM expressed by fractal dimension (Df). Mean values \pm SEM, $\mathrm{n}=8-16$, ${ }^{* * * *} P<0.001$ vs. control group.

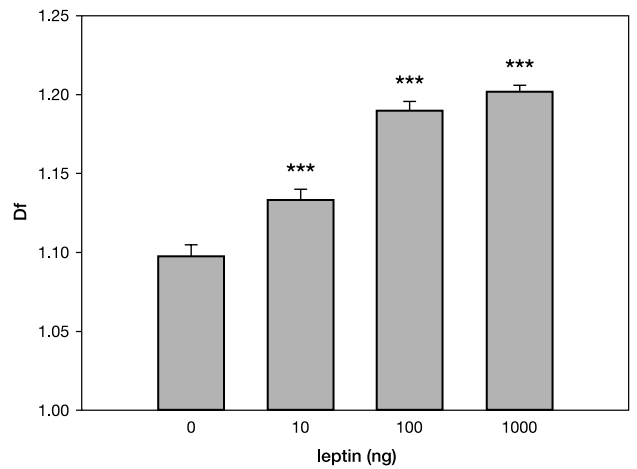

Fig.4. Effect of leptin administered in ovo at embryonic day 5 on angiogenesis in quail CAM expressed by fractal dimension (Df). Mean values \pm SEM, $\mathrm{n}=12-16$, ${ }_{* * * *} P<0.001$ vs. control group.

\section{Discussion}

Recent studies have addressed the possibility that leptin may either induce angiogenesis or influence efficiency of angiogenic factors (Sierra-Honigmann et al. 1998; Cao et al. 2001). Our study of quail CAM under two experimental conditions clearly demonstrated that leptin enhanced the formation of new blood vessels. The results are in accordance with the data obtained using chicken CAM (Bouloumié et al. 1998; Ribatti et al. 2001). Bouloumié et al. (1998) applied leptin at ED9 at higher doses (0.2, 1, and $3 \mu \mathrm{g}$ of leptin) onto methylcellulose discs. The doses of 1 and $3 \mu \mathrm{g}$ resulted in a marked stimulation of neovascularization. Thus, the stimulation of angiogenesis was observed after administration of higher concentrations of leptin than in our experiment. Ribatti et al. (2001) confirmed the stimulatory effect of leptin on angiogenesis after its administration onto chick CAM at ED8 on gelatine sponges at doses of 250,500 a $1000 \mathrm{ng}$, but not $100 \mathrm{ng}$. The stimulating effect of leptin was specific, since the exposure to anti-leptin antibodies significantly inhibited the angiogenic response. The angiogenic response of leptin was similar to that obtained with fibroblast growth factor 2 (FGF-2). However, the administration of leptin to CAM together with anti FGF-2 antibodies reduced the angiogenic effect of leptin by approximately $40 \%$, indicating that the activation of endogenous FGF-2 mediated at least in part leptin action (Ribatti et al. 2001). Recent data obtained with quail CAM demonstrate that leptin acts also in cooperation with the vascular endothelial growth factor (VEGF) inducing more significant changes than VEGF in vessel length and tortuousity (Talavera-Adame et al. 2008). An important finding supporting the idea of leptin effects on angiogenesis was the identification of leptin receptors in endothelial cells and mouse adipose tissue while its expression was not proved in adipose tissue and endothelial cells in leptin receptor-deficient ( $d b / d b)$ mice (Bornstein et al. 2000).

The murine leptin administration in ovo accelerated growth and development in quail embryos (Máčajová et al. 2002; Lamošová et al. 2003). Injection of 100 and 1000 ng leptin into egg albumen at ED5 of incubation stimulated the embryonic and postnatal development. The treated quail embryos hatched 18-22 $\mathrm{h}$ earlier than controls. Therefore, we used the same doses and experimental conditions also in this in ovo study. The mechanisms of avian embryonic growth and development acceleration by leptin are not clear. An increased vascular fenestration was documented in new corneal blood vessels after leptin treatment (Cao et al. 2001). Therefore, we speculate that the increased leptin content can stimulate development of CAM and subsequent transport and exchange of 
small molecules between the embryo and yolk. Since the existence or structure of the natural ligand for the leptin receptors in birds is still a matter of discussion, we suggest $\mathrm{CAM}$ as a promising model for solving this question.

The CAM serves as the respiratory organ for exchange of gases between pores of the eggshell and the dense network of capillaries and plays a role in electrolyte transport and mobilization of calcium transport from the shell (Reizis et al. 2005). The CAM assay is a useful and convenient model that has been used for understanding the role of different compounds in angiogenesis control and development of a promising anti-cancer drug (Richardson and Singh 2003). There are several modifications of CAM assay performed under ex ovo and in ovo conditions that have their advantages and disadvantages. For example the ex ovo approach allows better quantification of blood vessels over a wider area of the CAM than in ovo approach, which is limited by a small window in the eggshell. However, physiological conditions are better mimicked by the in ovo approach. In addition to the standard ex ovo approach we used in our study also in ovo administration of leptin that interferes less with the physiological status of embryo and offers better quantification of vessels. Quantification of angiogenic effects in ovo was done in the planar part of CAM under the egg's air cell. This CAM part seems interesting in connection with earlier findings related to regional variations of shell pore density and gas conductance (Rokitka and Rahn 1987) as well as blood vessel morphometry (Reizis et al. 2005). The capacity for CAM gas exchange can be assessed by the ratio between the eggshell pore density and CAM blood vessel density. Rokitka and Rahn (1987) found regional differences in shell pore density and shell gas conductance in six different avian species. All species displayed a decrease in regional shell conductance and pore density from the blunt end to the pointed end. Reizis et al. (2005), studying blood vessel morphometry in the chick CAM, determined higher blood vessel numerical density, area fraction of blood vessels and total length of blood vessels in the CAM under the air cell in relation to the rest of the CAM at ED10-ED20.

In conclusion, our results confirmed the angiogenic action of leptin in the quail CAM. We expect that the leptin-mediated stimulation of angiogenesis may contribute to the acceleration of quail embryo growth and development and this model can be useful for identification of avian leptin and its mechanism of action in birds. New modification of CAM assay in unfenestrated eggs can be advantageous for studying physiological effects of biological compounds on vessel development.

\section{Účinok leptínu na angiogenézu v chorioalantoickej membráne prepelice japonskej}

Leptín, produkt $o b$ génu, môže okrem funkcie endokrinného hormónu zodpovedného hlavne za reguláciu telesnej hmotnosti a príjmu potravy, pôsobit' aj parakrinne, ako rastový faktor ovplyvňujúci vývin. Ciel'om našej štúdie bolo sledovat účinok leptínu in vivo na angiogenézu v prepeličej chorioalantoickej membráne (CAM), a tak poukázat' na jeho rastový efekt potvrdený $\mathrm{v}$ predchádzajúcich štúdiách. Rekombinantný myšací leptín (10, 100 a 1000 ng) bol aplikovaný bud' ex ovo na povrch CAM izolovaných embryí v 7. dni embryonálneho vývinu alebo in ovo v 5. dni do bielka. Zmeny v cievnej štruktúre CAM boli kvantifikované pomocou fraktálnej analýzy, určením fraktálnej dimenzie (Df). Leptín podaný in ovo bol aktívnejší v stimulovaní angiogenézy meranej v CAM pod vzduchovou komôrkou, kde už 10 ng dávka vyvolala štatisticky významne vyššiu stimuláciu $(P<0.001)$ v porovnaní s ex ovo aplikáciou. Získané výsledky potvrdzujú angiogénny efekt exogénneho leptínu $v$ chorioalantoickej membráne prepelice japonskej. Leptínom sprostredkovaná stimulácia angiogenézy môže zlepšit' využitie živín zo žĺtka a prispievat' k akcelerácii rastu a vývinu vtáčích embryí. 


\section{Acknowledgements}

This study was supported by the Grant Agency for Science of the Slovak Republic VEGA 1/4343/07. We are grateful to Helena Rojčíková for her technical assistance.

\section{References}

Abramoff MD, Magelhaes PJ, Ram SJ 2004: Image Processing with ImageJ. Biophot Int 11: 36-42

Ashwell CM, McMurtry JP, Wang XH, Zhou Y, Vasilatos- Younken R 1999: Effects of growth hormone and pairfeeding on leptin mRNA expression in liver and adipose tissue. Domest Anim Endocrinol 17: 77-84

Bornstein SR, Abu-Asab M, Glasow A, Päth G, Hauner H, Tsokos M, Chrousos GP, Scherbaum WA 2000: Immunohistochemical and ultrastructural localization of leptin and leptin receptor in human white adipose tissue and differentiating human adipose cells in primary culture. Diabetes 49: 532-538

Bouloumié A, Drexler HC, Lafontan M, Busse R 1998: Leptin, the product of Ob gene, promotes angiogenesis. Circ Res 83: 1059-1066

Cao R, Brakenhielm E, Wahlestedt C, Thyberg J, Cao Y 2001: Leptin induces vascular permeability and synergistically stimulates angiogenesis with FGF-2 and VEGF. Proc Natl Acad Sci 98: 6390-6395

Campfield LA, Smith FJ, Guisez Y, Devos R, Burn P 1995: Recombinant mouse OB protein: evidence for a peripheral signal linking adiposity and central neural networks. Science 269: 546-549

Falkner E, Eder C, Kapeller B, Fröschl W, Schmatz C, Macfelda K, Losert UM 2004: The mandatory CAM testing of cells and scaffolds for tissue engineering: benefits for the three Rs of cooperation with the vaccine industry. Altern Lab Anim 32: 573-580

Horev G, Einat P, Aharoni T, Eshdat Y, Friedman-Einat M 2000: Molecular cloning and properties of the chicken leptin receptor (CLEPR) gene. Mol Cell Endocrinol 162: 95-106

Kirchner LM, Schmidt SP, Gruber BS 1996: Quantitation of angiogenesis in the chick chorioallantoic membrane model using fractal analysis. Microvasc Res 51: 2-14

Lamošová D, Máčajová M, Zeman M, Mózeš Š, Ježová D 2003: Effect of in ovo leptin administration on the development of Japanese quail. Physiol Res 52: 201-209

Máčajová M, Lamošová D, Zeman M 2002: Role of leptin in Japanese quail development. Acta Vet Brno 71: 473-479

Máčajová M, Lamošová D, Zeman M 2004: Role of leptin in farm animals: a review. J Vet Med 51: 151-166

Ohkubo T, Tanaka M, Nakashima K 2000: Structure and tissue distribution of chicken leptin receptor (cOb-R) mRNA. Biochim Biophys Acta 1491: 303-308

Ohkubo T, Adachi H 2008: Leptin signaling and action in birds. J Poultry Sci 45: 233-240

Parsons-Wingerter P, Lwai B, Yang MC, Elliott KE, Milaninia A, Redlitz A, Clark JI, Sage EH 1998: A novel assay of angiogenesis in the quail chorioallantoic membrane: Stimulation by bFGF and inhibition by angiostatin according to fractal dimension and grid intersection. Microvasc Res 55: 201-214

Parsons-Wingerter P, Elliott KE, Clark JI, Farr AG 2000: Fibroblast growth factor-2 selectively stimulates angiogenesis of small vessels in arterial tree. Arterioscler Thromb Vasc Biol 20: 1250-1256

Reizis A, Hammel I, Ar A 2005: Regional and developmental variations of blood vessel morphometry in the chick embryo chorioallantoic membrane. J Exp Biol 208: 2483-2488

Ribatti D, Nico B, Belloni AS, Vacca A, Roncali L, Nussdorfer GG 2001: Angiogenic activity of leptin in the chick embryo chorioallantoic membrane is in part mediated by endogenous fibroblast growth factor-2. Int $\mathrm{J}$ Mol Med 8: 265-268

Ribatti D, Conconi MT, Nussdorfer GG 2007: Nonclassic endogenous regulators of angiogenesis. Pharmacol Rev 59: $185-205$

Richardson M, Singh G 2003: Observations on the use of the chorioallantoic membrane (CAM) model in investigations into angiogenesis. Current Drug Targets-Cardiovascular and Haematological Disorders 3: 155-185

Rokitka MA, Rahn H 1987: Regional differences in shell conductance and pore density of avian eggs. Respir Physiol 68: 371-376

Sierra-Honigmann MR, Nath AK., Murakami C, García-Cardeña G, Papapetropoulos A, Sessa WC, Madge LA, Schechner JS Schwabb MB, Polverini PJ, Flores-Riveros JR 1998: Biological action of leptin as an angiogenic factor. Science 281: 1683-1686

Talavera-Adame D, Xiong Y, Zhao T, Arias AE, Sierra-Honigmann MR, Farkas DL 2008: Quantitative and morphometric evaluation of the angiogenic effects of leptin. J Biomed Opt 13(6):064017-1 -064017-7

Taouis M, Chen JW, Daviaud C, Dupont J, Derouet M, Simon J 1998: Cloning the chicken leptin gene. Gene 208: $239-242$ 

Plate III

Výboh P. et al.: Angiogenic Effect ... pp. 13-18
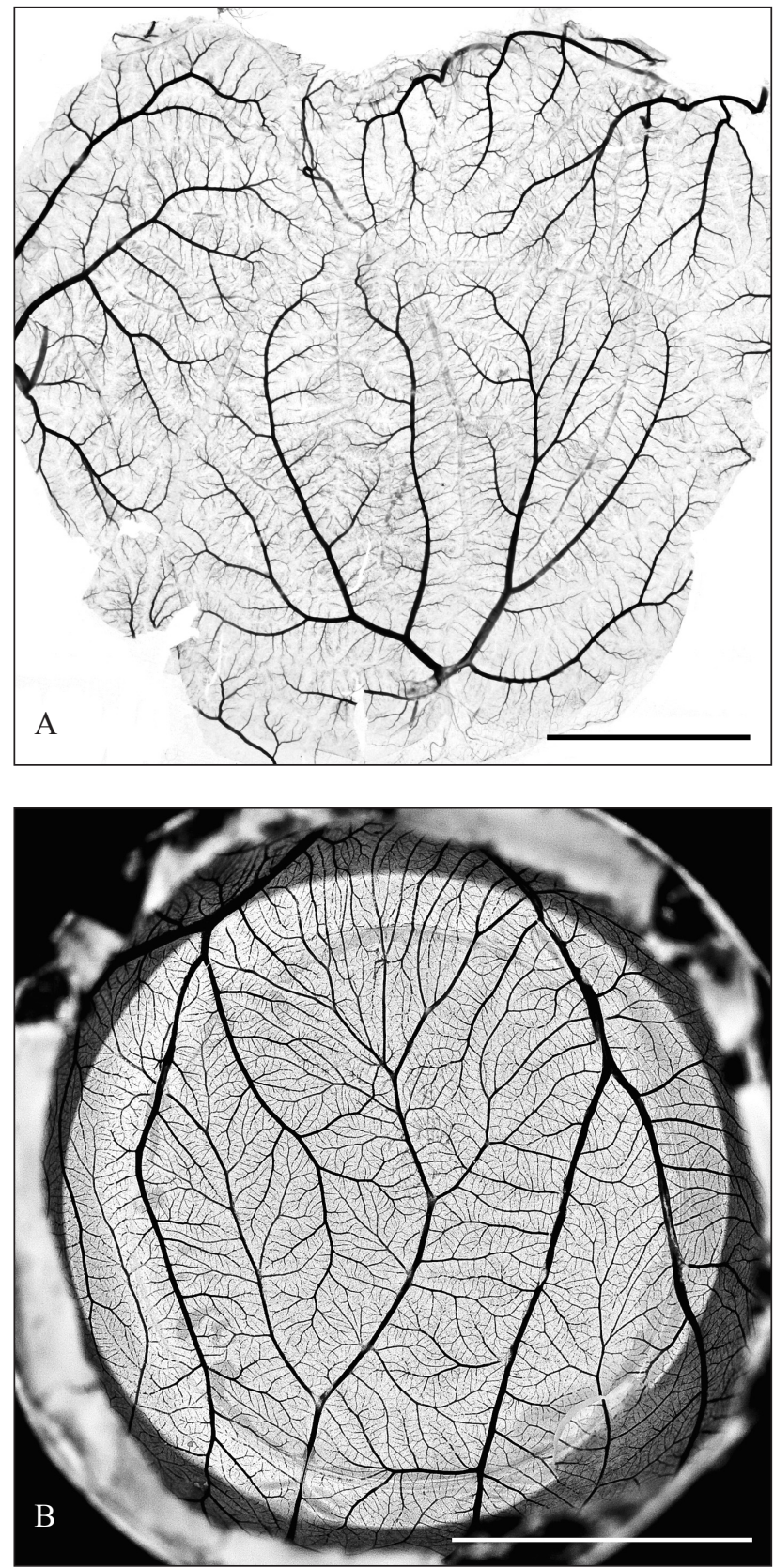

Fig. 1. Images of CAM after greyscale conversion. A - ex ovo approach, membrane mounted on glass slide; $\mathrm{B}-$ in ovo approach, membrane under air cell. Bar $=5 \mathrm{~mm}$. 




Fig. 2. Example of square $512 \times 512$ pixel selection $(3.5 \times 3.5 \mathrm{~mm})$ used for analysis. $\mathrm{A}$ - adjusted grayscale image; $\mathrm{B}$ - binarized image; $\mathrm{C}$ - skeletonized image 